\title{
Biofermentasi Kefir Teh Pecut Kuda (Stachytarpheta jamaicensis) Sebagai Sumber Belajar Biologi
}

\author{
Pramita Laksitarahmi Isrianto \\ Pendidikan Biologi, FBS, Universitas Wijaya Kusuma Surabaya \\ Email: laksitarahmi@yahoo.co.id
}

\begin{abstract}
Abstrak
Water kefir merupakan produk hasil biofermentasi dari larutan gula yang berasal dari simbiosa bakteri dan yeast dalam bentuk polisakarida banyak bermanfaat untuk kesehatan. Keanekaragaman tanaman di Indonesia sangatlah banyak dijadikan sebagai tanaman obat, salah satunya adalah Pecut Kuda (Stachytarpheta jamaicensis). Dikarenakan potensi sumber daya Pecut Kuda banyak akan manfaatnya sehingga bisa dijadikan media alternatif pertumbuhan probiotik dengan menggunakan larutan teh Pecut Kuda (Stachytarpheta jamaicensis). Kombinasi larutan teh Pecut Kuda (Stachytarpheta jamaicensis) dengan kefir grain diharapkan memberikan efek fungsional ganda bagi kesehatan tubuh. Metode penelitian ini menggunakan Rancangan Acak Lengkap (RAL) dengan 4 taraf perlakuan yaitu: konsentrasi larutan teh Pecut Kuda 10\% dan 15\% dengan lama fermentasi 12 jam dan 24 jam. Hasil penelitian ini menunjukkan berpengaruh nyata antar perlakuan terhadap $\mathrm{pH}$ $(\mathrm{p}=0,01)$, total asam asetat $(\mathrm{p}=0,03)$, total gula $(\mathrm{p}=0,00)$, dan total polifenol $(\mathrm{p}=0,00)$. Nilai $\mathrm{pH}$ diperoleh ratarata 3,32-4,34, untuk total asam asetat rata-rata $0,46-0,82 \%$, hasil total gula rata-rata 4,45-7,58\% dan total polifenol $0,11-3,41 \%$. Sedangkan hasil uji organoleptik antar perlakuan menunjukkan pengaruh nyata $(\mathrm{p}=0,00)$ terhadap parameter rasa,aroma, warna, dan daya. Perlakuan P1 dengan konsentrasi teh Pecut Kuda 10\% dengan lama fermentasi 12 jam lebih disukai panelis.
\end{abstract}

Kata kunci : water kefir, teh Pecut Kuda (Stachytarpheta jamaicensis), biofermentasi

\section{PENDAHULUAN}

Water kefir adalah minuman biofermentasi berasal dari simbiosis golongan bakteri dan yeast berbahan baku larutan gula. Water kefir atau disebut juga kefir grain, mampu menghasilkan etanol relatif rendah, karbon dioksida, asam-asam organik (laktat dan asetat), dan kandungan lemak yang ada sedikit jumlahnya.

Kefir bisa dijadikan sebagai stabilisator, pengemulsi, agen pembentuk gel dan memiliki aktivitas antimikroba serta anti tumor (Cheirsile et al., 2018). Minuman kefir banyak mengandung butirbutir kefir putih atau kuning yang tak larut dalam air dengan ukuran yang tidak beraturan. Berbagai macam mikroorganisme akan saling ber- simbiosis mutualisme terdiri dari kelompok yeast antara lain: Kluyveromyces, Candida, Saccharomyces, dan Pichia, sedangkan dari kelompok bakteri asam laktat yaitu Lactobacillus, Lactococcus, Leuconostoc, Streptococcus serta ada kelompok bakteri asam asetat lainnya (Plessas, et all., 2017).

Water kefir belum terlalu banyak diproduksi, biasanya masyarakat mengenal kefir dari susu. Namun terkadang timbul kekhawatiran akan intoleransi glukosa semakin meningkat sehingga memicu ketersediaan minuman non-susu dan mayoritas masyarakat lebih memilih golongan vegitarian (Mubin dan Elok, 2016). Oleh sebab itu, disarankan bahan baku water kefir ini berasal dari larutan teh herbal salah satunya dengan Pecut Kuda (Stachytarpheta jamaicensis).

Teh merupakan minuman yang diseduh. Hampir semua bagian tanaman Pecut Kuda (Stachytarpheta jamaicensis) bisa digunakan, mulai dari daun, batang, akar, kulit kayu, bunga, hingga kulit buahnya. Potensi sumber daya dengan kearifan lokal pada Pecut Kuda (Stachytarpheta jamaicensis) sangat banyak manfaatnya bagi kesehatan tubuh, diantaranya, dapat mengobati kencing batu, sakit radang tenggorokan, batuk, radang hati, hepatitis, keputihan, dan lain sebagainya. Kandungan yang dimiliki Pecut Kuda adalah alkaloid, glikosida, dan flavonoid (Dalimartha, 2000).

Kefir teh memiliki efek kesehatan sebagai antioksida. Produk minuman water 
kefir banyak manfaatnya dalam mengontrol kadar kolesterol dalam darah, mengurangi resiko kanker atau tumor pada saluran pencernaan, menjaga fungsi imunitas, diare, memperbaiki daya cerna laktosa, dan mencegah alergi (Lestari et al., 2018). Penggunaan kombinasi larutan teh Pecut Kuda dengan kefir grain diharapkan memberikan efek yang baik bagi kesehatan dari teh herbal dan efek fungsional dari teh Pecut Kuda sendiri sehingga bisa dijadikan sumber belajar biologi dan menghasilkan suatu minuman beralkohol dengan nilai gizi yang tinggi. Tujuan dari penelitian ini dalam penggunaan kombinasi larutan teh Pecut Kuda dengan kefir grain ini untuk mengetahui total gula, total asam, total polifenol, dan $\mathrm{pH}$ pada medium serta uji organoleptik.

Beberapa penelitian kefir yang pernah dilakukan oleh Muizuddin dan Elok (2015) yaitu mengenai aktivitas antibakteri kefir daun sirsak (Annona muricata) dari berbagai merk dipasaran, menunjukkan bahwa penggunaan teh daun sirsak merk kereta uap merupakan perlakuan terbaik dengan total BAL (Bakteri Asam Laktat) $6,89 \times 10^{10}$, total gula $6,80 \%$. Selanjutnya Musdholifah \& Elok (2016) juga melaporkan tentang aktivitas antioksidan kefir teh daun sirsak merk kereta uap menunjukkan hasil aktivitas antioksida $57,50 \%, \mathrm{pH} 4,54$, total asam 0,10\%. Penelitan lain yang telah dilakukan oleh Randazzo et al. (2016) yaitu tentang pengembangan minuman fermentasi kefir non susu dari juz buah anggur, kiwi, apel menunjukkan hasil peningkatan jumlah bakteri asam laktat dan yeast sehingga memberikan efek antioksidan.

Hasil Penelitian Mubin \& Elok (2016), menyatakan bahwa pembuatan kefir dapat dilakukan dari salah satu produk hasil pohon siwalan (Borasus flabelifer) yaitu nira siwalan. Hasil dari penelitiannya menunjukkan perlakukan terbaik kefir nira siwalan dengan metode inkubasi suhu $25^{\circ} \mathrm{C}$ selama 24 jam dengan pengenceran nira siwalan 1:7 yakni dengan nilai total BAL $5,63 \times 10^{7} \mathrm{cfu} / \mathrm{mL}$, total khamir $1,20 \times 10^{6} \mathrm{cfu} / \mathrm{mL}$, total asam $0,86 \%$, dan total gula sebesar10,33\%. Akan tetapi penggunaan water kefir dari larutan teh Pecut Kuda ini masih jarang dilakukan. Oleh karena itu, perlu adanya penelitian tentang biofermentasi kefir teh Pecut Kuda (Stachytarpheta jamaicensis) dengan lama fermentasi yang berbeda sehingga diharapkan menjadi minuman fungsional yang baik bagi kesehatan tubuh.

\section{METODOLOGI}

Penelitian ini dilakukan pada bulan Mei sampai dengan Juli 2019 di Laboratorium Biologi, Fakultas Bahasa dan Sains Universitas Wijaya Kusuma Surabaya.

Penelitian ini adalah penelitian eksperimen dengan rancangan acak lengkap (RAL) dengan 5 kali pengulangan yaitu variasi konsentrasi larutan teh pecut kuda $10 \%$ dan $15 \%$ dengan lama fermentasi 12 jam dan 24 jam.

Bahan dalam penelitian ini adalah teh Pecut Kuda (Stachytarpheta jamaicensis) dan kefir grain yang berasal dari Laboratorium Bioteknologi mikroba Fakultas Biokteknologi Universitas Surabaya. Bahan-bahan kimia yang digunakan untuk analisis yaitu buffer $\mathrm{pH} 4$ dan buffer $\mathrm{pH} 7$, indikator PP, aquades, reagen biuret, sukrosa, $\mathrm{NaOH} 0,1 \mathrm{~N}$, alkohol $70 \%$. Alat yang digunakan antara lain wadah kaca, saringan, beaker glass, autoclave, gelas ukur, $\mathrm{pH}$ meter, termometer air, timbangan digital, pipet tetes, pipe ukur, cawan petri, tabung reaksi, pengaduk kayu, sendok plastik, labu ukur $100 \mathrm{~mL}$, tabung ependorf, botol kaca, kuvet, pipet tetes toples besar, mikripipet, spektrofotometer UV-VIS, dan sentrifuge.

Adapun tahapan prosedur dalam penelitian adalah sebagai berikut: 1.Pembuatan larutan teh Pecut Kuda (Stachytarpheta jamaicensis) dengan konsentrasi $10 \%$ dan $15 \%$, 2. Penambahan bibit kefir grain 150 gram dalam $1 \mathrm{~L}, 3$. Penambahan 7-9 butir kismis sebagai nutrisi kefir grain pada water kefir teh 
Pecut Kuda yang telah dibuat. Kemudian dilakukan penyimpan dalam suhu ruang sesuai dengan perlakuan lama fermentasi 12 jam dan 24 jam. Setelah itu akan dilanjutkan dengan pengukuran total asam menggunakan metode titrasi, total polifenol dengan spektrofotometer UVVIS pada panjang gelombang $760 \mathrm{~nm}$, total gula dengan metode Luff Schoorl, dan untuk pengukuran $\mathrm{pH}$ dengan menggunakan $\mathrm{pH}$ meter. Data parameter $\mathrm{pH}$, total asam asetat, total gula, total polifeno dan hasil pengujian organoleptik (rasa,aroma,warna, dan daya tarik) pada 15 panelis akan dianalisis secara statistik dengan uji Anova.

\section{HASIL DAN PEMBAHASAN}

Data hasil pengujian water kefir teh Pecut Kuda (Stachytarpheta jamaicensis) terhadap uji organoleptik dapat dilihat pada tabel 1 dibawah. Hasil uji organoleptik (rasa, aroma, warna, dan daya tarik) water kefir teh Pecut Kuda diuji melalui 15 panelis pada mahasiswa semester 4 tahun akademik 2019/2020 dari Program Studi Pendidikan Biologi Universitas Wijaya Kusuma Surabaya.

Tabel 1. Hasil Rerata Uji Organoleptik

\begin{tabular}{|c|c|c|c|c|}
\hline \multirow{2}{*}{$\begin{array}{c}\text { Aspek } \\
\text { penilian }\end{array}$} & \multicolumn{4}{|c|}{ Skor Analisis Penilaian } \\
\hline & $\mathbf{P 1}$ & $\mathbf{P 2}$ & $\mathbf{P 3}$ & $\mathbf{P 4}$ \\
\hline Rasa & $\begin{array}{c}3,88^{\mathrm{d}} \pm 0,17 \\
6\end{array}$ & $2,77^{\mathrm{c}} \pm 0,25$ & $2,067^{\mathrm{b}} \pm 0,31$ & $1,08^{\mathrm{a}} \pm 0,176$ \\
\hline Aroma & $3^{\mathrm{c}} \pm 0,51$ & $2,49^{b} \pm 0,2$ & $2,01^{\mathrm{a}} \pm 0,58$ & $1,9^{\mathrm{a}} \pm 0,8$ \\
\hline Warna & $3,93^{\mathrm{d}} \pm 0,09$ & $2,83^{\mathrm{c}} \pm 0,25$ & $2,067^{\mathrm{b}} \pm 0,31$ & $1,11^{\mathrm{a}} \pm 0,18$ \\
\hline $\begin{array}{l}\text { Daya } \\
\text { tarik }\end{array}$ & $3,47^{\mathrm{d}} \pm 0,37$ & $2,48^{\mathrm{c}} \pm 0,53$ & $1,59^{\mathrm{b}} \pm 0,17$ & $1,37^{\mathrm{a}} \pm 0,36$ \\
\hline
\end{tabular}

Ket: $\mathrm{P} 1=$ konsentrasi teh pecut kuda $10 \%$ dan lama fermentasi 12 jam, P2= konsentrasi teh pecut kuda 15\% dan lama fermentasi 12 jam, P3= konsentrasi teh pecut kuda 10\% dan lama fermentasi 24 jam, P4= konsentrasi teh pecut kuda 15\% dan lama fermentasi 24 jam

Hasil dari pengujian organoleptik rasa menunjukkan perbedaan nyata $(\mathrm{p}=0,00)$ antara perlakuan. Pada tabel 1 dapat dilihat bahwa perlakuan P1 konsentrasi teh Pecut Kuda 10\% dan lama fermentasi 12 jam yaitu dengan rerata 3,88 rasa sedikit manis dan agak asam lebih banyak disukai panelis.

Rata-rata panelis lebih suka rasa yang tidak terlalu asam karena lebih toleran diperut panelis dibandingkan dengan rasa yang sangat asam. Reaktivitas konsentrasi larutan teh Pecut Kuda 10\% sangat cepat sehingga kombinasi alkohol dengan karbondioksida yang menghasilkan buih sudah bisa terlihat pada lama fermentasi 12 jam. Hal ini diduga adanya efek fungsional ganda dari larutan teh Pecut Kuda dengan kefir grain.
Berdasarkan hasil uji organoleptik pada kategori aroma menunjukkan hasil beda nyata $(\mathrm{p}=0,00)$ antar perlakuan P1 ,P2, dan P3. Rata-rata panelis menyukai perlakuan P1 konsentrasi larutan teh Pecut Kuda (Stachytarpheta jamaicensis) $10 \%$ dan lama fermentasi 12 jam dengan rerata 3 dengan aroma sedikit asam Semakin lama waktu fermentasi dengan konsentrasi teh Pecut Kuda (Stachytarpheta jamaicensis) yang semakin tinggi menyebabkan rasanya semakin masam dan aroma asamnya sangat kuat. Hal ini disebabkan aktivitas yeast dalam bibit water kefir sehingga menimbulkan aroma alkohol yang kuat berasal dari tingginya konsentrasi larutan teh dan stater yang digunakan dan lama waktu fermentasi. Organoleptik aroma merupakan parameter yang sulit diukur karena setiap panelis 
memiliki perbedaan dalam penciumannya. Aroma yang menyengat yang dihasilkan water kefir teh pecut Kuda berasal dari proses metabolisme yang terjadi selama fermentasi dalam kefir grain sehingga menghasilkan asam laktat dan asam asetat. Hal ini sejalan dengan penelitian Hastuti \& Joni (2016), menyatakan bahwa aroma menyengat dapat berasal dari adanya senyawa volatile yang mempengaruhi ketajaman aroma sehingga membentuk aroma yang khas dari kefir.

Katagori warna untuk water kefir teh Pecut Kuda rata-rata panelis suka dengan warna yang tidak terlalu pekat yaitu pada perlakuan perlakuan P1 yaitu konsentrasi teh Pecut Kuda 10\% dan lama fermentasi 12 jam menunjukkan warna coklat muda dengan nilai rerata 3,93 dan menujukkan beda nyata antar perlakuan $(p=0,00)$. Sedangkan hasil terendah terlihat pada perlakuan P4 yaitu konsentrasi teh Pecut Kuda $15 \%$ dengan waktu fermentasi 24 jam yaitu 1,1. Semakin lama fermentasi akan menghasilkan warna yang semakin pekat.

Hasil pengujian daya tarik panelis lebih suka pada perlakuan P1 menunjukkan beda nyata $(p=0,00)$ antar perlakuan. Perlakuan P1 pada larutan teh $10 \%$ dengan lama fermentasi 24 jam yaitu dengan nilai rerata panelis 3,47 mempunyai kategori warna kefir coklat muda, aroma sedikit asam dan tidak terlalu menyengat dengan rasa segar sedikit manis dan agak asam dengan khas rasa dari water kefir teh Pecut Kuda.Sedangkan pada perlakuan P4 tidak disukai panelis.

\section{Tabel 2. Rerata Total Ph}

\begin{tabular}{|c|c|}
\hline Perlakuan & Total pH (\%) \\
\hline P1 & $4,34^{\mathrm{c}} \pm 0,27$ \\
\hline P2 & $3,7^{\mathrm{b}} \pm 0,2$ \\
\hline P3 & $3,5^{\mathrm{ab}} \pm 0,12$ \\
\hline P4 & $3,32^{\mathrm{a}} \pm 0,29$ \\
\hline
\end{tabular}

Ket: $\mathrm{P} 1=$ konsentrasi teh pecut kuda $10 \%$ dan lama fermentasi 12 jam, P2= konsentrasi teh pecut kuda $15 \%$ dan lama fermentasi 12 jam, P3= konsentrasi teh pecut kuda $10 \%$ dan lama fermentasi 24 jam, P4= konsentrasi teh pecut kuda $15 \%$ dan lama fermentasi 24 jam

Pengukuran water kefir teh Pecut Kuda terhadap $\mathrm{pH}$ dapat dilihat pada tabel 2 di atas. Rerata $\mathrm{pH}$ water kefir teh Pecut Kuda menujukkan semakin lama waktu fermentasi dan semaki meningkatnya konsentrasi teh Pecut Kuda menunjukkan penuruan $\mathrm{pH}$. Perubahan nilai $\mathrm{pH}$ selama proses fermentasi 0 jam berkisar 6 , sedangkan selama proses biofermentasi 12 jam dengan konsentrasi stater $10 \%$ berkisar 3,5 hingga 4,43. Sedangkan untuk biofermentasi 24 jam dengan konsentrasi stater $15 \%$ berkisar 3,7 hingga 3,41. Terjadinya penurunan nilai $\mathrm{pH}$ menunjukkan adanya proses biofermentasi water kefir teh Pecut Kuda dengan kefir grain berlangsung, hal ini dikarenakan adanya akumulasi asam terjadi dari bakteri asam asetat dan asam laktat yang ada dalam bibit water kefir, sehingga menyebabkan rasa asam dan menimbulkan aroma khas dari water kefir teh Pecut Kuda. Hal ini sejalan dengan hasil penelitian yang dilakukan oleh Pertiwi et al., 2013 yaitu saat produksi asam laktat selama proses fermentasi akan mengubah nilai $\mathrm{pH}$. Dalam water kefir grain mengandung bakteri asam laktat dan yeast, yang berperan dalam fermentasi. Berdasarkan hasil analisis statistik water kefir teh Pecut Kuda terhadap nilai $\mathrm{pH}$ berpengaruh nyata dengan nilai $\mathrm{p}=0,01$. 
Tabel 3. Rerata Total Asam Asetat

\begin{tabular}{|c|c|}
\hline Perlakuan & Total Asam Asetat (\%) \\
\hline P1 & $0,46^{\mathrm{a}} \pm 0,055$ \\
\hline P2 & $0,51^{\mathrm{a}} \pm 0,005$ \\
\hline P3 & $0,72^{\mathrm{b}} \pm 0,027$ \\
\hline P4 & $0,82^{\mathrm{c}} \pm 0,027$ \\
\hline
\end{tabular}

Ket: P1 = konsentrasi teh pecut kuda10\% dan lama fermentasi 12, $\mathrm{P} 2=$ konsentrasi teh pecut kuda $15 \%$ dan lama fermentasi 12 jam, P3= konsentrasi teh pecut kuda $10 \%$ dan lama fermentasi 24 jam, P4= konsentrasi teh pecut kuda $15 \%$ dan lama fermentasi 24 jam

Perubahan total asam asetat yang terkadung dalam water kefir teh Pecut Kuda dapat dilihat pada tabel 3. Hasil analisis menunjukkan bahwa rerata total asam asetat selama proses biofermentasi 12 jam dengan konsentrasi stater $10 \%$ berkisar $0,46 \%$ hingga $0,72 \%$, sedangkan untuk lama fermentasi 24 jam dengan konsentrasi stater $15 \%$ berkisar $0,51 \%$ hingga $0,82 \%$. Semakin lama waktu fermentasi dan semakin banyak konsentrasi teh yang diberikan akan memberikan rasa asam pada water kefir teh ini dengan lama fermentasi 12 jam dan 24 jam. Akan tetapi berdasarkan hasil panelis lebih suka dengan water kefir Pecut Kuda yang segar dan tidak terlalu asam karena masih toleran diperut panelis. Adanya peningkatan total asam pada penelitian ini juga diduga karena penggunakan gula yang ditambahkan menjadikan sumber energi bagi kefir grain sehingga akumulasi asam laktat meningkat dan aktivitas dari bakteri asam laktat juga meningkat diikuti dengan penurunan $\mathrm{pH}$ medium.

Menurut Musdholifah dan Zubaidah (2016), menyatakan bahwa terjadinya aktivitas fermentasi kefir teh daun sisrsak karena adanya aktivitas kefir grain yang membentuk matriks polisakarida dan menghasilkan aroma alkohol seperti tape, peningkatan karbodioksida yang diiringi dengan meningkatnya asam laktat dan asam asetat dari hasil penguraian gula yang dimanfaatkan oleh aktivitas mikroorganisme untuk proses metabolime selama proses fermentasi. Oleh karena itu semakin lama proses biofermentasi maka total asam akan meningkat seiiring dengan peningkatan ketersediaan enzim dan yeast yang terbentuk tinggi dan terjadi pembentukkan alkohol yang optimal.

Menurut Ningsih et al, 2018 dalam penelitiannya menyatakan bahwa total asam merupakan intrepretasi dari besarnya jumlah asam laktat yang terbentuk dari hasil pemecahan laktosa oleh bakteri asam laktat dan akumulasi dari asam-asam organik. Terjadinya perubahan keasaman media merupakan suatu indikator adanya aktivitas metabolisme sel dalam memproduksi senyawa asam seperti asam asetat, asam laktat, dan asam piruvat (Priasty et al, 2013). Berdasarkan hasil uji analisis statistik water kefir teh Pecut Kuda terhadap total asam asetat yaitu berpengaruh nyata dengan nilai $\mathrm{p}=0,03$.

\section{Tabel 4. Rerata Total Gula}

\begin{tabular}{|c|c|}
\hline Perlakuan & Total Gula(\%) \\
\hline P1 & $7,58^{\mathrm{d}} \pm 0,35$ \\
\hline P2 & $6,08^{\mathrm{c}} \pm 0,18$ \\
\hline P3 & $5,42^{\mathrm{b}} \pm 0,38$ \\
\hline P4 & $4,45^{\mathrm{a}} \pm 0,27$ \\
\hline
\end{tabular}

Ket: P1 = konsentrasi teh pecut kuda10\% dan lama fermentasi 12 jam, P2= konsentrasi teh pecut kuda $15 \%$ dan lama fermentasi 12 jam, P3= konsentrasi teh pecut kuda $10 \%$ dan lama fermentasi 24 jam, P4= konsentrasi teh pecut kuda $15 \%$ dan lama fermentasi 24 jam

Hasil rerata total gula pada tabel 4 menunjukkan bahwa semakin lama waktu fermentasi total gula akan mengalami penurunan. Perubahan nilai total gula water kefir teh Pecut Kuda (Stachytarpheta jamaicensis) selama 12 jam pada 
konsetrasi stater $10 \%$ menujukkan nilai $7,58 \%$, sedangkan untuk konsetrasi stater $15 \%$ menunjukkan $6,08 \%$. Penelitian ini juga sejalan dengan Permatasari et al., (2018) yaitu semakin banyak penambahan gula maka akan menurunkan nilai $\mathrm{pH}$ menjadi. Terjadinya penurunan nilai total gula diduga karena aktivitas mikroorganisme meningkat dalam kefir grains dalam memecah sukrosa menjadi glukosa dan fruktosa dan selanjutnya glukosa oleh yeast digunakan untuk metabolisme sel dalam menghasilkan etanol dan karbodioksida. Hasil dari uji analisis statistik water kefir teh Pecut Kuda terhadap total gula memberikan pengaruh nyata dengan nilai $\mathrm{p}=0,000$.

Tabel 5. Rerata Total Polifenol

\begin{tabular}{|c|c|}
\hline Perlakuan & $\begin{array}{c}\text { Total Polifenol } \\
\mathbf{( \% )}\end{array}$ \\
\hline P1 & $0,11^{\mathrm{a}} \pm 0,05$ \\
\hline P2 & $2,11^{\mathrm{b}} \pm 0,06$ \\
\hline P3 & $3,28^{\mathrm{c}} \pm 0,17$ \\
\hline P4 & $3,41^{\mathrm{c}} \pm 0,11$ \\
\hline
\end{tabular}

Ket: P1 = konsentrasi teh pecut kuda $10 \%$ dan lama fermentasi 12 jam, P2= konsentrasi teh pecut kuda $15 \%$ dan lama fermentasi 12 jam, P3= konsentrasi teh pecut kuda $10 \%$ dan lama fermentasi 24 jam, P4= konsentrasi teh pecut kuda $15 \%$ dan lama fermentasi 24 jam

Berdasarkan hasil uji rerata total polifenol pada tabel 4 yaitu terjadi peningkatan perlakuan konsetrasi stater water kefir larutan teh Pecut Kuda (Stachytarpheta jamaicensis) pada 10\% dan $15 \%$ selama 12 jam yaitu $0,11 \%$ dan $2,11 \%$. Untuk konsetrasi stater water kefir larutan teh Pecut Kuda (Stachytarpheta jamaicensis) $10 \%$ dan $15 \%$ selama 24 jam yaitu $3,28 \%$ dan $3,41 \%$. Selama proses biofermentasi ini akan terjadi peningkatan polifenol.

Pada water kefir teh Pecut Kuda ini mempunyai enzim yang menghasilkan polifenol, di duga mampu diduga memiliki bioaktivitas terhadap antibakteri. Di mana senyawa polifenol ini dibutuhkan untuk mensintesis mikroorganisme dalam proses fermentasinya sehingga nantinya dapat menghasilkan alkohol dan karbondioksida. Sejalan dengan hasil penelitian dari Hidayat et al (2018), menunjukkan bahwa peningkatan total polifenol setelah melalui fermentasi yang diperoleh dari kefir Rosella liofilisat dengan $\mathrm{pH} 3$ dan total asam $1,71 \%$. Benar adanya jika total polifenol meningkat dikarenakan jumlah konsentrasi teh Pecut Kuda (Stachytarpheta jamaicensis) yang diberikan semakin banyak. Dikarenakan selama proses fermentasi dalam daun teh akan menghasilkan $30-40 \%$ polifenol yaitu senyawa katekin, sehingga memberikan antioksida yang kuat lebih dari vitamis $\mathrm{E}$, vitamin $\mathrm{C}$ dan betakaroten (Trubus, 2012). Berdasarkan hasil uji analisis statistik water kefir teh Pecut Kuda terhadap total polifenol juga berpengaruh nyata dengan nilai $\mathrm{p}=0,000$.

\section{KESIMPULAN}

Hasil penelitian ini dapat disimpulkan bahwa water kefir dengan konsentrasi larutan teh Pecut Kuda (Stachytarpheta jamaicensis) $10 \%$ dan $15 \%$ dengan lama fermentasi 12 jam dan 24 jam memberikan pengaruh nyata terhadap total $\mathrm{pH}(\mathrm{p}=0,01)$, total asam asetat $(\mathrm{p}=0,03)$, total gula $(\mathrm{p}=0,00)$, dan total polifenol $(\mathrm{p}=0,00)$.

Hasil pengujian organoleptik water kefir Pecut Kuda (Stachytarpheta jamaicensis) antar perlakuan berpengaruh nyata $(\mathrm{p}=0,00)$ terhadap parameter rasa, aroma, warna dan daya tarik panelis. Pada Perlakuan P1 lebih disukai panelis sehingga penelitian ini bisa dijadikan minuman fungsional yang bermanfaat bagi kesehatan.

\section{UCAPAN TERIMA KASIH}

Terima kasih saya sampaikan kepada: Tim LPPM Universitas Wijaya Kusuma Surabaya atas bantuan dana yang telah dinerikan dan Dekan Fakultas Bahasa 
dan Sains atas bantuan fasilitas laboratorium selama penelitian.

\section{REFERENSI}

Cheirsilp, Benjamas, Suwannee Suksawang, Jarudha Yeesang, \& Piyarat Boonsawang. 2018. CoProduction of Functional Exopolysaccharides and Lactic Acid by Lactobascillus kefiranofaciens Originated From Fermented milk, Kefir. J. Food Sci Technol. Vol. 55 (1): 331-340.

Dalimartha, Setiawan. 2000. Atlas Tumbuhan Obat Indonesia. Bogor: Trubus Agriwidya.

Hidayat, Ahmad, Amrianto, Jauhari, Aprilia Maipa, Sri Rahayu A.S, Achmad Himawan. 2018. Pengaruh Fermentasi Liofilisat Kefir Rosela (Hibiscus sabdarifa L.) Terhdapa Kadar Polifenol Total. Hasanuddin Student Journal Vol.2(1): 2018211.

Hastuti, Alifah \& Joni Kusnadi. 2016. Organoleptik dan Karakteristik Fisik Kefir Teh Rosella Merah (Hibiscus sabdariffa L) Dari Teh Rosella Merah Dari Pasaran. Jurnal Pangan dan Agroindustri Vol. 4 (1): 313-320.

Lestari, Martha Widi, V. Priyo Bintoro, Heni Rizqiati. 2018. Pengaruh Lama Fermentasi Terhadap Tingkat Keasaman, Viskositas, Kadar Alkohol, dan Mutu Hedonik Kefir Air Kelapa. Jurnal Teknologi Pangan Vol.2 (1): 8-13.

Mubin, M. Fatkhul, Elok Zubaidah. 2016. Studi Pembuatan Kefir Nira Siwalan (Borassus flabellifer L.) (Pengaruh Pengenceran Nira Siwalan dan Metode Inkubasi). Jurnal Pangan dan Agroindustri Vol. 4 No.1: 291-301.

Muizuddin, Muhammad, Elok Zubaidah. 2015 Aktiivtas Antibakteri Kefir Teh Daun Sisrak. Jurnal Pangan dan Agro Industri Vol 4. No.1.
Musdholifah, Elok Zubaidah. 2016. Studi Aktivitas Antioksida Kefir Teh Daun Sirsak Dari Berbagai Merk Dipasaran. Jurnal Pangan dan Agroindustri Vol.4 No.1: 29.

Ningsih, Desnandia Radhika, V. Priyo Bintoro, Nurwantoro. 2018. Analisis Total Padatan terlarut, kadar Alkohol, Nilai pH dan total Asam Pada Kefir Optima Dengan Penambahan High Fructose Syrup (HFS). Jurnal Teknologi Pangan Vol. 2 (2): 84-88.

Permatasari, Dwi Rumdaini I., Purwadi, Herly E. 2018. Kualitas Kefir Dengan Penambahan tepung Daun Stevia (Stevia rebaudiana Bertoni) Sebagai Pemanis Alami. Jurnal Ilmu dan Teknologi Hasil Ternak Vol.13 (2): 91-97.

Pertiwi, SRR, N.Novidahlia, I. Juliana. 2013 Perubahan Sifat Kefir Air Yang Difermentasi Pada Berbagai Suhu. Jurnal Pertanian Vol.4(1).ISSN 2087-4936.

Plessas, Stavros, Chrysanthi Nouska, Ioanna Mantzourani, Yiannis Kourkoutas, Athanasios Alexopoulos, \& Eygenia B.2017. Microbiological Exploratioan of Different Type of Kefir Grains. $J$. Fermentastion Vol. 3(1).

Priasty, Hasanuddin, \& Kurnia Herlina Dewi. 2013, Kualitas Asam Cuka Kelapa (Cocos nucifera L.) Dengan Metode Lambat (Slow Methods). Jurnal Agroindustri, Vol.3 (1):113.

Randazzo, Walter, Rosa Guarcello, Onofrio Corona, Nicola F. 2016. Development of New Non- Dairy Beverages From Mediterranean Fruit Juices Fermented With Water Kefir Microorganisms. Food Microbiology Vol.54-51

Trubus. 2012. Herbal Indonesia Berkhasiat, Bukti Ilmiah \& Cara Racik Vol.10. Jakarta: Trubus. 